\title{
A ESTABILIZAÇÃo DA TUTELA PROVISÓRIA DE URGÊNCIA ANTECIPADA NO NOVO CÓDIGO DE PROCESSO CIVIL
}

\author{
Artur César de Souza* \\ Rubia Cristina Sorrilha**
}

\section{RESUMO}

As inovações trazidas com novo Código de Processo Civil brasileiro, visam à resolução eficaz dos conflitos entre as partes, possibilitando o emprego do direito material de forma efetiva e sem burocracia. Dentre elas, merece destaque a inserção da técnica da estabilização dos efeitos das decisões tomadas sob cognição materialmente sumária, denominadas tutelas satisfativas antecedentes. O presente trabalho visa analisar as principais controvérsias em torno do instituto da estabilização na tutela provisória de urgência antecipada no novo Código de Processo Civil, partindo do estudo das tutelas jurisdicionais diferençadas. Emprega-se o método dedutivo, pesquisa doutrina e legislativa.

Palavras-chave: Novo Código de Processo Civil. Tutela Jurisdicional Diferenciada. Tutela de Urgência Antecipada. Cognição Sumária. Estabilização.

\section{THE STABILIZATION OF TEMPORARY URGENCY IN GUARDIANSHIP IN THE NEW CODE OF CIVIL PROCEDURE}

\begin{abstract}
The innovations brought by the new Brazilian Code of Civil Procedure aim at the effective resolution of conflicts between parties, enabling the use of material law effectively and without bureaucracy. Among them, noteworthy is the insertion of the stabilization technique of the effects of decisions taken under materially summary cognition, named anticipated satisfying guardianship. The present paper aims to analyze the main controversies around the stabilization institute in the provisional guardianship of anticipated urgency at the new Code of Civil Procedure, starting from the study of differentiated jurisdictional guardianship. The deductive method, doctrinal and legislative research are used.
\end{abstract}

Key-words: New Code of Civil Procedure. Differentiated Jurisdictional Guardianship. Previous Urgency Guardianship. Summary Cognition. Stabilization.

\section{INTRODUÇÃO}

Um dos pilares postos no modelo de Estado Liberal no século XIX, foi a garantia ao cidadão de proteção em face da atuação do poder estatal. Nesse período, a doutrina processual clássica solidificou a garantia da participação efetiva das partes durante todas as fases do

\footnotetext{
* Pós-Doutor em Direito pela Università Statale di Milano - Itália, pela Universidade de Valencia - Espanha, pela Faculdade de Direito da Universidade de Lisboa - Portugal e pela Universidade Federal de Santa Catarina. Juiz Federal na função de Juiz Auxiliar da Presidência do Tribunal Regional Federal da 4 a Região. Professor na Universidade Filadélfia, na Universidade Estadual de Londrina e na Universidade de Marília - UNIMAR.

${ }^{* *}$ Mestranda do Programa de Mestrado em Direito da Universidade de Marília - UNIMAR. Advogada.
} 
processo, por meio do contraditório amplo e exauriente, na busca de um direito fundamentado em maior nível de certeza jurídica e material.

Mais tarde, com o surgimento do Estado Social passou a ser assegurado aos cidadãos além das garantias já abarcadas no Estado Liberal, o direito ao gozo do conceito de bem-estar social. Com essa alteração, sobreveio a necessidade inevitável de disseminação das tutelas jurisdicionais diferençadas, na busca de equacionar o desacerto entre a dilação temporal inerente aos procedimentos ordinários e a prestação jurisdicional útil e efetiva, ante às peculiaridades de determinados direitos que necessitavam ser tutelados na busca da almejada paz social.

A prestação efetiva da tutela jurisdicional fundamentalmente liga-se ao princípio do acesso à justiça, que corresponde a um direito fundamental que deve ser assegurado pelo Estado Democrático de Direito, garantindo-lhe ampla aplicabilidade.

O novo Código de Processo Civil brasileiro, instituído pela Lei 13.105, de 16 de março de 2015, estabelece em seus artigos 294 a 311 a denominada "tutela provisória" que perfaz a ampla categoria que abarca tanto as tutelas de urgência, que se subdividem em cautelar e antecipada, como compreende também a tutela de evidência.

Basicamente esses novos institutos baseiam-se na premissa, já assumida pelo Código de Processo Civil de 1973, de que as tutelas calcadas em cognição sumária são, salvo algumas exceções, precárias, já que podem ser revertidas a qualquer momento, e ainda, provisórias, pois necessitam de uma tutela definitiva para se tornarem aptas a constituir a coisa julgada.

Não devemos olvidar que o Código de Processo Civil de 1973 foi essencial nos últimos anos, todavia, naquela época o número de demandas era inferior ao registrado atualmente. Ademais, com o surgimento das demandas em massa, a ausência de uniformidade das decisões e a inserção do uso de novas tecnologia, constituíram fatores decisivos para a elaboração do novo Código de Processo Civil.

O novo Código de Processo Civil brasileiro previu a possibilidade de as tutelas de urgência serem formuladas antes do pedido de tutela definitiva, por intermédio de mera petição, que evidencie o fumus boni iuris e o periclum in mora. Tal regra foi posta para as cautelares e para as tutelas antecipadas satisfativas em caráter antecedente, esta última, objeto do presente estudo.

O legislador previu, ainda, no artigo 304 do novo Código de Processo Civil, o instituto da estabilização para as tutelas antecipadas satisfativas em caráter antecedente, que ocorre quando a parte demandada não recorre da decisão proferida sumariamente e a parte 
autora anui na obtenção tão somente da cognição sumária, sem que sobrevenha o seu trânsito em julgado.

O presente trabalho visa, fundamentalmente, avaliar os principais aspectos do instituto da estabilização da tutela provisória de urgência antecipada previsto nos artigos 303 e 304 do novo Código de Processo Civil brasileiro e, as controvérsias em torno da estabilidade conferida ao provimento antecipatório.

Este artigo, em primeiro momento, busca definir os conceitos de tutela jurisdicional e tutelas jurisdicionais diferenciadas. Em seguida, avalia os pressupostos para a concessão da técnica de estabilização no novo Código de Processo Civil brasileiro. Após, realiza breves apontamentos a respeito da tutela de urgência satisfativa em caráter antecedente e do instituto da estabilização da tutela provisória no ordenamento jurídico brasileiro. Ao final, afere os pontos controvertidos a respeito da estabilização da tutela de urgência satisfativa em caráter antecedente instituída novo Código de Processo Civil brasileiro.

Para tanto, emprega o método dedutivo, tendo como foco a doutrina e a legislação que envolvem o tema.

\section{DEFINIÇÃO DE TUTELA JURISDICIONAL E DE TUTELA JURISDICIONAL DIFERENCIADA}

Antes de adentrar ao escopo do presente trabalho, faz-se imprescindível aclarar as definições de tutela jurisdicional e de tutela jurisdicional diferenciada.

A Constituição Federal de 1988 instituiu em seu artigo 5º inciso XXXV o princípio da ubiquidade (ou da inafastabilidade do controle jurisdicional) ao prever que: "Nenhuma lesão ou ameaça a direito será subtraída à apreciação do Poder Judiciário". 1 Já o caput do artigo $5^{\circ}$, estabelece o princípio da isonomia ao descrever que: "Todos são iguais perante a lei, sem distinção de qualquer natureza". ${ }^{2}$ Além disso, a Magna Carta em seu artigo $5^{\circ}$, inciso LIV assegura, o direito ao contraditório e à ampla defesa e, no inciso LV garante o devido processo legal. Todas as previsões constitucionais acima elencadas visam, de certa forma, assegurar ao cidadão o acesso à justiça como um direito constitucional.

Dentre as previsões constitucionais acima exposta, ganha destaque o princípio da ubiquidade (ou da inafastabilidade do controle jurisdicional), que confere ao Estado-Juiz a

\footnotetext{
${ }^{1}$ BRASIL. Constituição da República Federativa do Brasil de 1988. Disponível em: $<$ http://www.planalto.gov.br/ccivil_03/constituicao/constituicaocompilado.htm>. Acesso em: 27 set. 2016. s.p.

2 Op. cit. s.p.
} 
incumbência perante seus concidadãos de tutelar eventuais direitos que se encontrem sob ameaça ou que já tenham sido violados. Embora o Estado-Juiz possua o monopólio da jurisdição, existem situações amparadas pelo ordenamento jurídico brasileiro que possibilitam ao cidadão a proteção de seu direito subjetivo ou o emprego de qualquer meio lícito mediante uma tutela jurídica.

Hodiernamente, o acesso à justiça não pode ser confundido com o acesso ao Poder Judiciário, vez que o mero ajuizamento de uma demanda não acarreta, necessariamente na certeza de justiça da decisão proferida e, muito menos, da celeridade da atividade jurisdicional.

Segundo ensinamento de Nelson Nery Junior, a garantia constitucional que merece resguardo pelo Estado Democrático de Direito não visa garantir ao cidadão apenas o direito à tutela jurisdicional, mas à tutela jurisdicional adequada e efetiva. ${ }^{3}$ A respeito do exposto, Theodoro Júnior dispõe que:

No Estado Democrático de Direito, o objetivo da jurisdição não é mais visto como apenas realizar a vontade concreta da lei, mas a de prestar a tutela ao direito material envolvido em crise de efetividade [...] Tutelar os direitos, portanto é a função da Justiça e o processo é o instrumento por meio do qual se alcança a efetividade dessa tutela. ${ }^{4}$

Portanto, o acesso à justiça deve ser compreendido como a obtenção da tutela jurisdicional, por meio de mecanismos que facilitem o ingresso em juízo e, que proporcionem meios para o desenvolvimento adequado e efetivo do processo. Assim, como o direito de ação, direito público subjetivo, cívico e abstrato perfaz um direito, agasalhado pelo artigo $5^{\circ}$, inciso XXXV da Magna Carta, e o processo é o instrumento da realização do direito material, a todo cidadão deve ser garantido o direito de uma resposta (pronunciamento do Estado-Juiz) favorável ou não, quanto ao litígio deduzido, produzindo uma efetiva preservação do direito material e do bem da vida ao vencedor. Define Cândido Rangel Dinamarco que:

[...] tutela jurisdicional não é o mero exercício da jurisdição, ou somente a outorga do provimento jurisdicional em cumprimento ao dever estatal que figura como contraposto do poder de ação. A ação em si considera-se satisfeita e exaurida sempre que emitido esse provimento, quer seja favorável ou desfavorável. É, portanto, um conceito indesejavelmente

\footnotetext{
${ }^{3}$ NERY JÚNIOR, Nelson. Princípios do processo civil na Constituição Federal. São Paulo: Revista dos Tribunais RT, 2002. p. 37

${ }^{4}$ THEODORO JÚNIOR, Humberto. Curso de Direito Processual Civil. v. I. 56 ${ }^{\text {a }}$ ed. Rio de Janeiro: Forense, 2015. p. 595
} 
técnico, para quem busca resultados - e o processo civil de hoje é um processo civil de resultados. ${ }^{5}$

Como bem definido acima, o processo civil atualmente deve ser de resultados. Não basta a prolação de uma sentença, se ela não for efetiva, eficaz e principalmente se ela não conseguir entregar o bem da vida à parte vencedora. A respeito do acima exposto, complementa Flávio Luiz Yarshell que:

[...] parece não haver dúvida de que a locução tutela jurisdicional se presta a designar o resultado da atividade jurisdicional - assim considerados os efeitos substanciais (jurídicos e práticos) que o provimento final projeta ou produz sobre dada relação material - em favor do vencedor. ${ }^{6}$

Os processualistas contemporâneos consideram a efetividade do processo como um instrumento da tutela de direitos, um dos principais desafios a serem alcançados na atualidade. Desse modo, definida a noção de tutela jurisdicional (amparo jurídico e prático à parte vencedora) passa-se a avaliar o sentido da expressão tutela jurisdicional diferenciada.

A expressão tutela jurisdicional diferenciada pode ser compreendida como a predisposição de métodos, procedimentos e meios não ordinários postos pelo legislador para que a atividade processual se revista de qualidade e efetividade. $\mathrm{O}$ autor Andrea Proto Pisani, que pioneiramente estudou o tema em 1973, apresenta que a expressão "tutela jurisdicional diferenciada", em síntese, deve ser compreendida como a restrição à atividade cognitiva realizada pelo Estado-Juiz ao proferir sua resposta ao litígio deduzido. Ou seja, o modelo neutro e único de processo ordinário de cognição plena, tradicionalmente instituído, passa a agregar mecanismos que visam o alcance da efetividade do processo e resguardo da satisfação da pretensão principal da parte por meio de uma cognição sumária e célere.

É cediço que nem todas as situações postas à apreciação do Poder Judiciário necessitam de uma cognição plena e aprofundada ou quiçá de processo com fases demarcadas e longas para que ocorra a entrega jurisdicional justa e que assegure o devido processo legal, ao contrário, o modelo processual classicamente construído - garantidor de amplo contraditório e preocupado com plena instrução probatória - poderia levar à depreciação ou mesmo à perda do bem da vida discutido enquanto se construía, nos moldes legalmente prescritos, o material que tornava apta a plena cognição do julgador.

\footnotetext{
${ }^{5}$ DINAMARCO, Cândido Rangel. Tutela jurisdicional. São Paulo: Revistas de Processos, ano 21, n. 81, 1996. p. 54

${ }^{6}$ YARSHELL, Flávio Luiz. Tutela jurisdicional. São Paulo: Atlas, 1999. p. 28
} 
Segundo Antônio Carlos Marcato, o principal atributo da tutela jurisdicional diferenciada, seja com relação aos provimentos provisórios ou em relação aos provimentos judiciais definitivos ou finais, é a sumariedade da atividade e de cognição pelo juiz para a prolação de sua decisão. ${ }^{7}$ Portanto, essa sumariedade deve ser compreendida como uma restrição à atividade cognitiva, com exame restrito, dos elementos pelo juiz para a formação de sua convicção e de sua decisão. Define Alexandre Freitas Câmara que "cognição é a técnica utilizada pelo juiz para, através da consideração, análise e valoração das alegações e provas produzidas pelas partes, formar juízos de valor acerca das questões suscitadas no processo, a fim de decidi-las". 8

As restrições à atividade cognitiva incidem tanto no plano vertical (profundidade) em que a cognição pode ser sumária (incompleta) ou exauriente (completa); como no plano horizontal (extensão), quando a cognição pode ser plena ou parcial. Ou seja, incidem tanto nos casos de tutela provisória, como nas ações sumárias, onde há o provimento definitivo sem a necessidade de cognição exauriente pelo juiz. Com efeito, sob o enfoque apresentado, se aparentam contraditórias as normas constitucionais que instituem os primados da efetividade processual e da segurança jurídica. Nas demandas onde a cognição é plena (mais aprofundada) há maior segurança ao juiz para analisar todos as questões postas.

Por outro lado, o processo de cognição plena e aprofundada, perde efetividade à medida que a tutela jurisdicional não é entregue de forma dinâmica as partes. Desse modo, por ser a efetividade processual e a segurança jurídica, dois direitos constitucionais de mesma origem e hierarquia, a solução para a ajuste entre eles é o emprego de medidas de caráter provisório e de cognição sumária, as quais se nomeiam tutela jurisdicional diferenciada.

Define Ricardo de Barros Leonel que a tutela jurisdicional diferenciada deve ser compreendida como a "proteção jurídica e prática outorgada pelo Estado-Juiz, resultante da utilização de procedimentos especiais previstos no ordenamento processual, em que a celeridade de efetividade a prestação jurisdicional decorram da limitação da cognição". 9 Andrea Proto Pisani, elenca três justificativas para a adoção das tutelas diferenciadas:

[...] (a) in primo luogo quando la tutela somaria sia direta ad evitarei il costo del processo a cognizione piena e exauriente, ove manchi uma seria volontà di contestazione da parte dellóbbligato. È questa la giustificazione

\footnotetext{
${ }^{7}$ MARCATO, Antônio Carlos. O processo monitório brasileiro. São Paulo: Malheiros, 1998. p. 27

${ }^{8}$ CÂMARA, Alexandre Freitas. Lições de Direito Processual Civil. v. I. Rio de Janeiro: Editora Freitas Bastos, 1998. p. 249

${ }^{9}$ LEONEL, Ricardo de Barros. Tutela jurisdicional diferenciada. São Paulo: Revista dos Tribunais, 2010. p. 25
} 
razionale che sta alla base della tecnica del procedimento monitório, [...]; (b) in secondo luogo quando la tutela sommaria sia direta ad evitare che il convenuto abusi del diritto di defesa garantitogli dalle forme del processo a cognizione piena ed exauriente: per reagire a tale pericolo insito nella durata (anche meramente fisiologica) propria della struttura di um processo c.d. ordinário, il legislatore può utilizzare sia la tecnica delle misure cautelari conservative (emanate sulla base della mera cognizione sommaria dell'esisteneza del dirirro e del periculum in mora), sia la tecnica della c.d. condena com riserva ova la prova dei fatti constitutivi del diritto vantato dall'attore presenti caratteri di particolare attendibilità e le eccezioni del convenuto appaiano infondate ad una prima delibazione sommaria [...]; (c) in terzo luogo, infine, il recordo atta tutela sommaria è; razionalmente justificato quando essa sia direta a garantire l'effetività della tutela giurisdizioale com riferimento a tutte quelle situazioni di vantagio, a tutti quei diritti, che, avendo contenuto elo funzione (exclusivamente o prevalentemente) non patrimoniale, subirebbero (rectius: $i$ cui titolari subirebbero) um pregiudizio irreparabile (non suscettibile cioè ti tutela adeguata nella forma dell'equivalente monetário) ove dessevero permanere in uno stato di insoddisfazione per tutto il tempo necessário per la emanazione di uma sentenza (esecutiva) a termine di um processo a cognizione piena e exauriente. ${ }^{10}$

Em suma, a primeira justificativa apresentada pelo autor, reside na redução de gastos com o processo de cognição completa (exauriente) quando não há apresentação de resistência pela parte demanda; a segunda justificativa visa evitar o abuso do direito de defesa por parte do réu que, manifestamente, não possua motivos justos para a resistência; e a última justificativa, tende a garantir a efetividade da tutela jurisdicional em determinadas situações, mormente, quando o direito não apresente conteúdo econômico direto e, onde a espera pela parte possa ocasionar prejuízo irreparável ou de difícil reparação. Acrescenta Ricardo de Barros Leonel, que haveriam outros elementos nessa concepção:

(a) proteção jurídica e prática outorgada pelo Estado-juiz, ou seja, a premissa conceitual da noção de tutela jurisdicional;

(b) a utilização de procedimentos especiais, que, embora por si só não seja elemento suficiente à conceituação da tutela diferenciada, participa da construção de sua definição junto a outros elementos;

(c) celeridade e efetividade, que são os escopos da tutela diferenciada, e acabam por integrar a construção do seu conceito;

(d) limitação da cognição, dado que particulariza esta espécie de tutela jurisdicional, e exclui de seu âmbito a generalização indevida para todo e qualquer procedimento especial. ${ }^{11}$

\footnotetext{
${ }^{10}$ PISANI, Andrea Proto. Sulla tutela giurisdizionale diferenziata. Padova: Rivista di Diritto Processuale, v. XXXIV, II série, 1979. p. 568

${ }^{11}$ LEONEL, Ricardo de Barros. Tutela jurisdicional diferenciada. São Paulo: Revista dos Tribunais, 2010. p. 25
} 
Em síntese, a tutela jurisdicional diferenciada pode ser definida como a predisposição de métodos, técnicas e meios não ordinários postos pelo legislador para a restrição da atividade cognitiva do juiz, e visando a produção de resultados, no processo, que sejam mais efetivos, tanto pelas decisões provisórias como de decisões derradeiras.

\section{PRESSUPOSTOS PARA A UTILIZAÇÃO DA TÉCNICA DE ESTABILIZAÇÃO DA TUTELA PROVISÓRIA ANTECEDENTE}

O novo Código de Processo Civil brasileiro estabelece uma categoria geral denominada "tutela provisória" e a considera de acordo com três dimensões: Na primeira dimensão, é preciso analisar o que pode ser tutelado provisoriamente. Essa dimensão é estudada a partir de seu conteúdo, podendo ser satisfativa ou cautelar.

$\mathrm{Na}$ segunda dimensão, é preciso analisar o motivo pelo qual se concede tutela provisória, nessa dimensão, a análise foca a necessidade ou não de se demonstrar a existência do perigo de demora da prestação da tutela jurisdicional. Estudam-se, pois, sobre esse viés, os pressupostos que autorizam a concessão da tutela provisória, podendo ser ela de urgência ou de evidencia. Finalmente, a técnica exige a análise acerca do momento em que é pleiteada a tutela provisória, ou seja, o momento em que é postulada seu pedido ao Estado-Juiz, podendo ser antecedente ou incidente.

Da leitura dos artigos 294, parágrafo único e 311 do novo Código de Processo Civil, apura-se que a técnica da estabilização não se aplica à tutela provisória de evidência. Já da leitura dos artigos 294, caput, 305, 310, e 311 do novo Código de Processo Civil, constata-se que a estabilização também não se aplica à tutela provisória de urgência cautelar. E, por fim, da regulação trazida pelos artigos 294, caput e 295 do novo Código de Processo Civil, constata-se que a técnica da estabilização igualmente não se aplica à tutela provisória requerida em caráter incidente.

Superados tais apontamentos e observado que a técnica da estabilização somente se aplica às tutelas provisórias de urgência antecedentes, passa-se à análise dos pressupostos para a aplicação dessa técnica.

Os artigos 303 e 304 do novo Código de Processo Civil brasileiro exibem quatro pressupostos cumulativos a serem preenchidos para a aplicação da técnica da estabilização: o primeiro exige que a petição formulada pelo autor contenha pedido expresso de aplicação da técnica da estabilização; o segundo estabelece que o magistrado, após a análise sumária do 
pedido de tutela provisória de urgência antecedente, defira a tutela antecipada pleiteada; o terceiro estabelece que a decisão concessiva da tutela antecipada pleiteada seja proferida em caráter liminar; e por último exige-se que o réu, após devidamente comunicado do deferimento da tutela provisória de urgência antecedente, não interponha recurso.

Realizadas tais considerações, passa-se ao estudo de cada um dos pressupostos, acima mencionados, para a concessão da técnica de estabilização.

\subsection{REQUERIMENTO DA TUTELA PROVISÓRIA SATISFATIVA ANTECEDENTE}

O primeiro pressuposto, para a concessão da técnica da estabilização na tutela provisória de urgência antecipada, é retirado do disposto nos artigos 301 e 302 do novo Código de Processo Civil e se refere à exigência de que haja pedido expresso do autor para fazer jus a tal benefício.

Por constituir um benefício como prevê o artigo 303, $\$ 5^{\circ}$, do novo Código de Processo Civil, não pode ser prestado, caso não seja requerido expressamente pela parte autora, uma vez que a parte que o postula possui o direito de eleger se almeja correr os riscos próprios do prosseguimento do processo, visando conseguir uma tutela final apta a constituir a coisa julgada material.

Ademais, não se pode obrigar que a parte, que pleiteia a tutela provisória de urgência antecipada, se satisfaça unicamente com a estabilização da tutela provisória, a qual pode inclusive ser rediscutida por demanda contrária, movida pela parte adversa, conforme estabelece o artigo 304, $\S 5^{\circ}$ do novo Código de Processo Civil.

Inclusive, caso for desrespeitado o direito de a parte eleger se almeja a estabilização da tutela provisória, ou se pretende a obtenção da tutela final apta a constituir a coisa julgada material, ocorrerá flagrante violação à garantia da inafastabilidade da jurisdição (ou da ubiquidade da justiça), assegurada no artigo $5^{\circ}$, inciso XXXV da Magna Carta.

Dispõe o caput do artigo 303 do novo Código de Processo Civil que:

Art. 303. Nos casos em que a urgência for contemporânea à propositura da ação, a petição inicial pode limitar-se ao requerimento da tutela antecipada e à indicação do pedido de tutela final, com a exposição da lide, do direito que se busca realizar e do perigo de dano ou do risco ao resultado útil do processo. $^{12}$

${ }^{12}$ BRASIL. Lei $n^{o} 13.105$, de 16 de março de 2015. Disponível em: <http://www.planalto.gov.br/ccivil_03/_ato2015-2018/2015/lei/113105.htm〉. Acesso em: 28 set. 2016. s.p. 
Já o caput do artigo 304 do novo Código de Processo Civil dispõe que "a tutela antecipada, concedida nos termos do artigo 303, torna-se estável se da decisão que a conceder não for interposto o respectivo recurso". ${ }^{13}$

Denota-se da leitura acima, que o artigo 303 do novo Código de Processo Civil possibilita duas posições à parte que solicita a tutela antecipada: o pedido exclusivo da tutela provisória urgente satisfativa, ou o pedido tanto da tutela provisória urgente satisfativa como da tutela final.

Só na primeira posição, ocorre a estabilização, eis que, na segunda posição, desde o início, deixa-se claro que a parte almeja algo além do que somente a tutela provisória estabilizada.

\subsection{DECISÃO CONCESSIVA DA TUTELA PROVISÓRIA DE URGÊNCIA ANTECEDENTE}

O segundo pressuposto para a concessão da técnica da estabilização na tutela provisória de urgência antecipada é a existência de uma decisão de primeiro ou segundo grau concessiva da tutela antecipada pleiteada.

Importante destacar que somente os efeitos da decisão positiva podem tornar-se estáveis.

Logo, uma primeira corrente capitaneada por Fredie Didier Junior, considera que o disposto no artigo 304 do novo Código de Processo Civil tem aptidão para a estabilidade tanto das decisões concessivas proferidas em primeiro grau, como das decisões tanto monocráticas ou colegiadas proferidas em recurso de agravo de instrumento. ${ }^{14}$

Lado oposto ao acima, uma segunda corrente capitaneada pelo doutrinador Artur César de Souza considera que a "estabilização somente ocorrerá quando a tutela antecipada for concedida pelo juízo de primeiro grau e não em grau superior". ${ }^{15}$

De outra parte, grande parte da doutrina é unânime em afirmar que é possível a estabilização também das decisões proferidas em processos cuja competência original é do tribunal.

\footnotetext{
${ }^{13}$ Op. cit. s.p.

${ }^{14}$ DIDIER JÚNIOR, Fredie. Curso de direito processual civil: teoria da prova, direito probatório, ações probatórias, decisão, precedentes, coisa julgada e antecipação dos efeitos da tutela. 11. ed. v.2. Salvador: Ed. Jus Podivm, 2016. p. 620

${ }^{15}$ SOUZA, Artur César de. Tutela provisória: tutela de urgência e tutela de evidência. São Paulo: Almedina, 2016. p. 198
} 


\subsection{DECISÃO PROFERIDA LIMINARMENTE OU APÓS A JUSTIFICAÇÃO PRÉVIA}

O terceiro pressuposto para a concessão da técnica da estabilização na tutela provisória de urgência antecipada exige que a decisão da medida seja concedida liminarmente ou após a justificação prévia.

Pela leitura do artigo $300, \S 2^{\circ}$ do novo Código de Processo Civil, extrai-se que a tutela provisória apta a se estabilizar é aquela concedida liminarmente ou após a justificação prévia.

Assim, explica Fredie Didier Junior que se o juiz indeferir o pedido formulado em instância de primeiro grau, e a parte autora agravar dessa decisão, sendo concedida a tutela provisória em decisão monocrática ou colegiada, nessa hipótese, se não tiver ocorrido o aditamento da peça inicial por parte do autor com a formulação do pedido de tutela definitiva, é perfeitamente possível a ocorrência da estabilização da decisão que houver deferido a medida em grau de recurso. ${ }^{16}$

\subsection{INÉRCIA DO RÉU}

O último pressuposto exige que o réu, citado e intimado da decisão que concede a tutela antecipada não interponha recurso nem outro meio de impugnação.

Segundo defende Fredie Didier Junior, embora o artigo 304 do novo Código de Processo Civil referira-se apenas a não interposição de recurso, a inércia que se compreende para a estabilização da tutela, estabelece que o réu não interponha recurso nem outro meio de impugnação dessa decisão. ${ }^{17}$ Em igual sentido, entende Cássio Scarpinella Bueno, inclusive destacando que o melhor entendimento é aceitar a interpretação ampliativa do disposto no caput do artigo 304 do novo Código de Processo Civil, devendo ser admitida qualquer manifestação expressa em sentido contrário. ${ }^{18}$

Por outro lado, defendem alguns doutrinadores, como Artur César de Souza, que a ideia do legislador repousaria somente na interpretação de ser possível a estabilização quando

\footnotetext{
${ }^{16}$ DIDIER JÚNIOR, Fredie. Curso de direito processual civil: teoria da prova, direito probatório, ações probatórias, decisão, precedentes, coisa julgada e antecipação dos efeitos da tutela. 11. ed. v.2. Salvador: Ed. Jus Podivm, 2016. p. 620

${ }^{17}$ Op. cit. p. 621

${ }^{18}$ BUENO, Cássio Scarpinella. Manual de direito processual civil: inteiramente estruturado à luz do novo CPC, de acordo com a Lei 13.256, de 4-2-2016. 2. ed. São Paulo: Saraiva. 2016. p. 262.
} 
o réu não interpuser o recurso de agravo de instrumento previsto no artigo 1.015, inciso I do novo Código de Processo Civil; ou outra hipótese de impugnação por meio de recurso, tal como o pedido de suspensão de tutela preventiva fixada no artigo $4^{\circ}$ da Lei $n^{\circ} 8.437 / 92 .{ }^{19}$ Inclusive, os defensores desse entendimento, sobretudo o próprio Artur César de Souza interpreta que: "a reação do réu à concessão da tutela antecipada antecedente seja por meio de 'recurso' e não outra forma de impugnação, como por exemplo, antecipação da contestação, pedido de reconsideração e outras similares". ${ }^{20}$

Se a decisão que conceder a medida for proferida em primeiro grau, o recurso adequado e apto para a sua concessão será o agravo de instrumento, conforme previsão dada pelo artigo 1015, inciso I do novo Código de Processo Civil. Já, se a decisão que conceder a medida for proferida em segundo grau, o recurso adequado e apto para essa situação, se a decisão for monocrática, será o agravo interno ou, se a decisão for colegiada, o recurso poderá ser: ou o recurso especial ou o extraordinário.

Outro ponto de grande relevância refere ao não conhecimento do recurso interposto pelo réu. Nessa hipótese, seja qual for o motivo do seu indeferimento, ele será apto a impedir a estabilização, pois a simples interposição já é suficiente para que não ocorra a estabilização. Ademais, o prazo da defesa somente deve começar a fluir a partir da audiência de conciliação ou mediação ou da data do protocolo do pedido de cancelamento. Todavia, caso já se verifique pela impossibilidade de composição, o prazo para a defesa começará a fluir após a devida intimação informando o réu do aditamento da petição inicial.

De outra parte, defende Fredie Didier Junior que, se no prazo do recurso, o réu antecipa o protocolo de sua defesa, deve-se considerar que houve oposição de sua parte e, por conseguinte, a estabilização ficará prejudicada. ${ }^{21}$ A fundamentação para o posicionamento acima exposto, baseia-se no fato de que não pode o juiz negar ao réu o direito de obter uma prestação jurisdicional de mérito definitiva, com aptidão à formação da coisa julgada, ou seja, o posicionamento consagra o direito constitucional da inafastabilidade da jurisdição (ou da ubiquidade da justiça) e do acesso à justiça.

\section{DA TUTELA DE URGÊNCIA SATISFATIVA EM CARÁTER ANTECEDENTE}

\footnotetext{
${ }^{19}$ SOUZA, Artur César de. Tutela provisória: tutela de urgência e tutela de evidência. São Paulo: Almedina, 2016. p. 199

${ }^{20}$ Op. cit. p. 199

${ }^{21}$ DIDIER JÚNIOR, Fredie. Curso de direito processual civil: teoria da prova, direito probatório, ações probatórias, decisão, precedentes, coisa julgada e antecipação dos efeitos da tutela. 11. ed. v.2. Salvador: Ed. Jus Podivm, 2016. p. 622
} 
A tutela provisória de urgência satisfativa antecedente é aquela requerida no início do processo, antes da formulação do pedido de tutela final, cujo escopo é adiantar seus efeitos. Assim, para a sua concessão deve o autor, por meio de mera petição, limitar-se ao pedido da tutela antecipada e a indicação do pedido de tutela definitiva, com exposição da lide, do direito que se busca realizar e do perigo de dano ou risco ao resultado útil do processo, nos termos do artigo 303 do novo Código de Processo Civil.

Deve também na petição, indicar o valor da causa, já considerado o que almejará na tutela definitiva, conforme fixa o artigo $303, \S^{\circ}$ do novo Código de Processo Civil e, por fim, que pretende se valer da tutela provisória antecedente, conforme estabelece o artigo 303, caput e $\$ 4^{\circ}$ do novo Código de Processo Civil.

Caso não seja ela concedida pelo juiz competente, por não estarem presentes os requisitos necessários ao seu deferimento, o autor será intimado para que realize a emenda da petição inicial em 5 (cinco) dias, sob pena de indeferimento e extinção do processo sem resolução do mérito. O intuito da emenda da petição inicial é fornecer à parte a oportunidade de complementação de sua causa de pedir, com a formulação do pedido de tutela definitiva e a juntada dos documentos necessários, conforme fixa o artigo $303, \S 6^{\circ}$ do novo Código de Processo Civil.

Uma vez concedida a tutela antecipada, o autor será intimado para que realize a emenda da petição inicial em 15 (quinze) dias, ou outro que o juiz fixar, sob pena de indeferimento e extinção do processo sem resolução do mérito, nos termos do artigo 303, §1 , incisos e $\$ 2^{\circ}$ do novo Código de Processo Civil. Tal aditamento inclusive é isento de nova custa processual, conforme fixa o artigo 303, $\$ 3^{\circ}$ do novo Código de Processo Civil. Concomitante a tal providência, o magistrado deverá proceder à citação e intimação da parte da demanda (réu) para o cumprimento da ordem deferida e, ainda, a intimação para comparecer à audiência de conciliação ou de medição nos termos do artigo 334 do novo Código de Processo Civil.

Realizada aludida audiência e não havendo composição entre as partes, o prazo para a apresentação de defesa na modalidade de contestação será computado a partir da audiência. O prazo para contestar não poderá se iniciar antes da emenda da petição inicial, inclusive porque não haverá ainda a formalização de pedido de tutela definitiva para o réu se defender; desse modo, ensina Fredie Didier Junior que mesmo se não for agendada a audiência de conciliação ou de medição, o prazo de defesa só iniciará da data em que for intimado do 
aditamento da petição inicial. ${ }^{22}$ Se o demandado apresentar defesa o processo seguirá o rito do procedimento comum. Caso permaneça inerte o processo poderá ser estabilizada.

\subsection{DA ESTABILIZAÇÃO}

A inspiração da estabilização advém do sistema processual italiano e baseia-se no sistema dos réferés franceses, visando afastar os prejuízos da demora do processo, bem como evitar o manejo de ações quando as partes já estiverem satisfeitas através da antecipação de tutela. $^{23}$ Em 2005, o Código de Processo Civil italiano foi alterado, estabelecendo que deferida a tutela antecipada, ela não pode perder a sua eficácia caso não exista o processo principal no prazo estabelecido pela lei, passando a apresentar estabilidade, deixando de possuir apenas aspecto instrumental. ${ }^{24}$ Desde então, o ajuizamento da ação passou a ser uma faculdade das partes, que somente se ambicionarem a tutela definitiva.

O Código de Processo Civil italiano prevê ainda, que a decisão da tutela antecipada não faz coisa julgada, podendo ser a qualquer momento revista enquanto não prescrita, constituindo uma decisão política, já que inexiste vedação constitucional neste sentido. ${ }^{25}$

No ordenamento jurídico brasileiro, uma decisão é apta a produzir efeitos independentemente de não ter se tornado imune à modificação ou revogações posteriores. A tutela provisória satisfativa antecedente, mesmo antes de estabilizar, é plenamente eficaz. Assim, atualmente, com a estabilização e a consequente extinção do processo, permite-se a execução definitiva, antes dela só se possibilitava a execução provisória.

\section{AS PRINCIPAIS CONTROVÉRSIAS A RESPEITO DA ESTABILIZAÇÃO DA TUTELA DE URGÊNCIA SATISFATIVA EM CARÁTER ANTECEDENTE}

O primeiro ponto controvertido a respeito da estabilização se refere ao deferimento parcial da tutela. Essa situação não foi prevista pelo legislador que somente estabeleceu no

\footnotetext{
${ }^{22}$ DIDIER JÚNIOR, Fredie. Curso de direito processual civil: teoria da prova, direito probatório, ações probatórias, decisão, precedentes, coisa julgada e antecipação dos efeitos da tutela. 11. ed. v.2. Salvador: Ed. Jus Podivm, 2016. p. 616

${ }^{23}$ BAUERMANN, Desirê. Estabilização da Tutela Antecipada. Revista Eletrônica de Direito Processual. REDP. v. VI. Ano 4. Periódico da Pós-Graduação Stricto Sensu em Direito Processual da UERJ. ISSN 1982-7636, 2010. p. 36

${ }^{24}$ BAUERMANN, Desirê. Estabilização da Tutela Antecipada. Revista Eletrônica de Direito Processual. REDP. v. VI. Ano 4. Periódico da Pós-Graduação Stricto Sensu em Direito Processual da UERJ. ISSN 1982-7636, 2010. p. 36

${ }_{25}$ Op. cit. p. 37
} 
artigo 304 novo Código de Processo Civil a hipótese de ocorrência da estabilização da concessão total da tutela, com a consequente inércia do réu e a extinção total do processo. A esse respeito há doutrinadores, como Artur César de Souza, que entendem que não se pode aventar a estabilização se o juiz conceder parte da tutela antecipada pleiteada, pois nesta situação a parte autora será sucumbente, por isso não se poderá aventar a extinção do processo sem resolução do mérito. ${ }^{26}$

No entanto, como o novo Código de Processo Civil prevê no artigo 356 a possibilidade de desmembramento do objeto litigioso e o acolhimento parcial do mérito, há quem defenda não ser coerente a recusa da estabilização parcial e, por conseguinte, a redução do objeto da demanda.

Ademais há quem defenda que o risco de a decisão final ser desfavorável ao autor e, eventualmente, ser contraditória com a decisão antecipatória estabilizada, não redundará numa contradição jurídica, e ocorrerá todas as vezes que não houver simultaneidade de processos. Para os defensores dessa corrente, igual raciocínio deve ser empregado na hipótese de recurso parcial, sendo estabilizada somente a matéria que não for recorrida.

O segundo ponto controvertido a respeito da estabilização se refere à hipótese em que o autor não adita a petição inicial após o deferimento da medida e não haja a interposição de recurso pelo réu em face da decisão concessiva da tutela provisória. Nessa situação, defende Fredie Didier Junior que deveria ser privilegiada a estabilização da tutela, em razão da possibilidade que ambas as partes possuem de rever, invalidar ou reformar a ação, conforme estabelece o artigo 304, $\$ 2^{\circ}$ do novo Código de Processo Civil. ${ }^{27}$

O terceiro ponto controvertido a respeito da estabilização se refere à fixação de verbas sucumbenciais. Nessa situação há aqueles que reputam que deve seguir a sistemática adotada na ação monitória do Código de Processo Civil de 1973, que considerava que o cumprimento espontâneo do mandado pelo réu o isentava da responsabilidade pelo custo do processo.

Há, ainda, aqueles, como o doutrinador Artur César de Souza que consideram que a decisão que extingue o processo se dá sem resolução de mérito, logo não seria cabível impor

\footnotetext{
${ }^{26}$ SOUZA, Artur César de. Tutela provisória: tutela de urgência e tutela de evidência. São Paulo: Almedina, 2016. p. 199

${ }^{27}$ DIDIER JÚNIOR, Fredie. Curso de direito processual civil: teoria da prova, direito probatório, ações probatórias, decisão, precedentes, coisa julgada e antecipação dos efeitos da tutela. 11. ed. v.2. Salvador: Ed. Jus Podivm, 2016. p. 623
} 
ao réu os pagamentos de custas processuais e honorários sucumbenciais, devendo inclusive essa isenção servir como um incentivo para que o réu evite dar prosseguimento à ação. ${ }^{28}$

Por outro lado, há aqueles, como Bruno Garcia Redondo que consideram que o correto seria a aplicação analógica do disposto no artigo 701, caput, do novo Código de Processo Civil, ou seja, a fixação de $5 \%$ (cinco por cento) de honorários sucumbenciais em face do réu inerte. ${ }^{29}$

Outra questão importante que gravita em relação à estabilização se refere à situação em que a citação do réu se dê por edital ou hora certa, quando ele estiver preso ou se for incapaz, sem representante. Nesses casos, grande parte da doutrina considera que deve ser designado para o réu curador especial para a sua defesa e para impugnar a tutela de urgência concedida. É pacifico na doutrina que não incidirá a estabilização caso o réu não recorra nem utilize nenhum outro meio de impugnação, mas houver a impugnação por parte de litisconsorte passivo ou do assistente litisconsorcial, cujos fundamentos aproveitem ao réu inerte.

Outro ponto interessante a ser pontuado se refere à não formação da coisa jugada após a estabilização e o decurso do lapso temporal de 2 (dois) anos, sem o ajuizamento de tutela de cognição plena e exauriente, conforme preveem expressamente os artigos $304, \S 5^{\circ} \mathrm{e}$ $\S 6^{\circ}$ do novo Código de Processo Civil:

\begin{abstract}
Art. 304. A tutela antecipada, concedida nos termos do art. 303, tornar-se estável se da decisão que a conceder não for interposto o respectivo recurso. $\S 5^{\circ} \mathrm{O}$ direito de rever, reformar ou invalidar a tutela antecipada, previsto no $\S 2^{\circ}$ deste artigo, extingue-se após 2 (dois) anos, contados da ciência da decisão que extinguiu o processo, nos termos do $\S 1^{\circ}$.

$\S 6^{\circ} \mathrm{A}$ decisão que concede a tutela não fará coisa julgada, mas a estabilidade dos respectivos efeitos só será afastada por decisão que a revir, reformar ou invalidar, proferida em ação ajuizada por umas das partes, nos termos do $\S 2^{\circ}$ deste artigo. ${ }^{30}$
\end{abstract}

O prazo de 2 (dois) anos definido pelo legislador é um prazo decadencial. Por isso, caso não haja o ajuizamento de ação dentro desse lapso temporal ter-se-á a estabilização definitiva da decisão sumária, sem a formação da coisa julgada.

\footnotetext{
${ }^{28}$ SOUZA, Artur César de. Tutela provisória: tutela de urgência e tutela de evidência. São Paulo: Almedina, 2016. p. 200

${ }^{29}$ REDONDO, Bruno Garcia. Estabilização, modificação e negociação da tutela de urgência antecipada antecedente: principiais controvérsias. Revista de Processo. São Paulo: RT, a 40, v. 244. Jun. 2015. p. 178

${ }^{30}$ BRASIL. Lei $n^{\circ} 13.105$, de 16 de março de 2015. Disponível em:

<http://www.planalto.gov.br/ccivil_03/_ato2015-2018/2015/lei/113105.htm>. Acesso em: 28 set. 2016. s.p.
} 
A opção legislativa pela não formação da coisa julgada baseia-se nas experiências observadas tanto da França como da Itália, onde seus legisladores proclamaram que as tutelas sumárias não operam a coisa julgada.

A literatura que defende a não formação da coisa julgada, dispõe que equipar um provimento de cognição plena e exauriente com um provimento de cognição sumária traduziria em violação constitucional ao devido processo e, por reflexo, na ampla defesa, insculpida no artigo $5^{\circ}$, inciso LIV da Constituição Federal e, no contraditório previsto no artigo $5^{\circ}$, inciso LV da Constituição Federal.

Ademais, a própria roupagem dada à coisa julgada material pelo novo Código de Processo Civil, exige a implementação de um contraditório pleno e efetivo, o que se torna incompatível com a cognição sumária.

Há quem sustente que após o transcurso de 2 (dois) anos sem o ajuizamento de tutela de cognição plena e exauriente, o que torna estável são os efeitos da decisão. Assim, como a coisa julgada recai sobre o conteúdo da decisão e não sobre seus efeitos, é somente o conteúdo que se tornam indiscutíveis com a coisa julgada e, não os efeitos, por isso, a estabilização da tutela satisfativa antecedente não se confunde com a coisa julgada. Inclusive para parte da doutrina não cabe ação rescisória da decisão que concede a tutela provisória após o transcurso de 2 (dois) anos para o ajuizamento da ação que se refere o $\$ 5^{\circ}$ do artigo 304 do novo Código de Processo Civil.

Ademais, mesmo sem os efeitos da coisa julgada, decorrido o lapso temporal de 2 (dois) anos sem o ajuizamento de tutela de cognição plena e exauriente, haverá do ponto de vista prático a estabilização definitiva, que caso seja rediscutida em nova ação, não acarretará na extinção com base no disposto no artigo 485, inciso V do novo Código de Processo Civil, mas poderá acarretar na rejeição do processo com resolução do mérito, com base na alegação de prescrição e decadência, conforme estabelece o artigo 487, inciso II do novo Código de Processo Civil.

Defende Artur César de Souza que na hipótese da demanda de mérito ser proposta após dois anos do prazo decadencial e sobrevir o reconhecimento de que aquele que está obrigado ao pagamento dos alimentos pela estabilização definitiva da tutela não seja o pai do beneficiário dos alimentos, nessa situação, muito embora o adequado fosse de fato a mantença do pagamento dos alimentos pela estabilização definitiva da tutela, visando evitar uma possível injustiça, o melhor seria a aplicação analógica do disposto no artigo 505, inciso II do novo Código de Processo Civil, que refere à coisa jugada e às situações de trato sucessivo, 
pois se a alteração do estado de fato ou de direito é capaz de afetar a sentença albergada pela coisa julgada, não teria sentido que a mesma "ratio legis" não fosse aplicada diante de uma decisão interlocutória estabilizada. ${ }^{31}$

Por fim, importante destacar que em sentido contrário ao acima exposto, há autores como Leonardo Greco que entendem que independentemente da situação posta há sempre a formação da coisa julgada ${ }^{32}$. Já Daniel Mitidiero defende que transcorrido o prazo de 2 (dois) anos há coisa julgada e, que por isso, há inconstitucionalidade da regra, ideia essa que não pactuamos. $^{33}$

\section{CONCLUSÃO}

Conclui-se, que a disciplina das tutelas provisórias no novo Código de Processo Civil se revela de suma importância para que a efetivação da tutela jurisdicional prestada pelo Estado-Juiz seja célere e eficaz.

Através da inserção do instituto da tutela provisória, houve a aquiescência por parte do legislador, de que o processo necessita estar sempre à disposição da concretização dos direitos previstos no ordenamento jurídico brasileiro e que as tutelas provisórias perfazem um meio que o magistrado possui de ofertar essa jurisdição de forma mais célere e apropriada.

A técnica da estabilização inserida na tutela antecipada satisfativa em caráter antecedente, calcada no disposto do artigo $5^{\circ}$, inciso LXXVIII da Constituição Federal, que prevê que todos possuem direito à razoável duração processual e aos meios que assegurem a agilidade de sua tramitação, bem como no artigo $4^{\circ}$ do novo Código de Processo Civil, que estabelece que as partes possuem o direito de obter a solução do mérito dentro de prazo razoável, como também o direito aos princípios da economia processual e ao da efetividade da tutela jurisdicional, visa, caso seja verificado entre as partes a satisfação somente com a tutela antecipada deferida, que se afastem os males decorrentes da excessiva demora para se obter o bem da vida almejado, bem como se evite a necessidade de se desenvolver um processo sem a

\footnotetext{
${ }^{31}$ SOUZA, Artur César de. Tutela provisória: tutela de urgência e tutela de evidência. São Paulo: Almedina, 2016. p. 207

${ }^{32}$ GRECO, Leonardo. A tutela de urgência e a tutela de evidencia no Código de Processo Civil de 2014/2015. Rio de Janeiro: Revista Eletrônica de Direito Processual Civil. 2014. ISSN 1982-7636. Disponível em: http://www.e-publicacoes.uerj.br/index.php/redp/article/download/14541/15862. Acesso em 09. abr. 2017. p. 315

${ }^{33}$ MITIDIERO, Daniel. Da tutela provisória. Breves comentários ao Código de Processo Civil. Teresa Wambier, Fredie Didier Jr. Eduardo Talamini e Bruno Dantas (coord.). São Paulo: RT, 2015. p. 790
} 
expressa pretensão resistida do réu - nos casos em que não impugnar a decisão estabilizando os efeitos da tutela antecipada deferida.

Verdade é que o legislador acabou por transferir ao réu o encargo pelo destino do processo nos casos em que o autor se contente apenas com a tutela antecipada deferida. Com isso, visa à redução de demandas desnecessárias.

Portanto, o novo Código de Processo Civil além de fortalecer o instituto das tutelas jurisdicionais diferenciadas, trazendo as modernas ideias do direito europeu, visa, em prol da economia processual, a implantação de forma alternativa de solução de conflitos diversa daquela prestada pelo tradicional processo de conhecimento.

Inclusive, o legislador a fim de evitar que a insegurança jurídica em relação à tutela satisfativa concedida perdure indefinidamente, possibilitou qualquer das partes, no prazo decadencial de 2 (dois) anos, computados da concessão da tutela satisfativa antecedente caso não se satisfaça com a estabilização, proponha ação autônoma com pedido de revisão, reforma ou invalidade da decisão, conforme estabelece o artigo $304, \S 2^{\circ}$ e $\$ 5^{\circ}$ do novo Código de Processo Civil brasileiro.

Ademais, a ausência de formação de coisa julgada proporciona, como se observa em institutos análogos no direito estrangeiro, que a técnica da estabilização perfaça um relevante expediente prático para a solução de situações peculiares sem que ocorra a estabilização total.

De outra parte, a formação da coisa julgada nas ações de cognição sumária fere, além do disposto no artigo 304, $\S 6^{\circ}$ do novo Código de Processo Civil, os próprios pressupostos instituídos pelo referido diploma legal, que determina a ocorrência de um contraditório dinâmico para a formação da coisa julgada, conforme prevê o artigo 503 do novo Código de Processo Civil.

Não devemos olvidar que o novo Código de Processo Civil, por ser um texto recém inserido em nosso ordenamento, encontrará certo receio e dificuldade por parte tanto dos operadores como dos julgadores em sua aplicação, mormente no que tange ao emprego da técnica da estabilização, pois não é da cultura brasileira a conciliação dos interesses entre as partes; ao contrário, no Brasil existe a falsa acepção de que somente a tutela definitiva coloca fim à lide entre as partes o que, pensamento esse que, a nosso ver, necessita ser modificado.

Por fim, inúmeras questões envolvendo a técnica da estabilização não foram previstas pelo legislador e, certamente, levarão certo tempo para que tornem pacíficas tanto pela jurisprudência e como pela própria doutrina. 
O presente trabalho não teve a pretensão de esgotar toda as questões que envolvem a técnica da estabilização no novo Código de Processo Civil brasileiro, mas trouxe à tona o estudo de alguns aspectos jurídicos relevantes da inserção do instituto da estabilização previsto nos artigos 303 e 304 do novo Código de Processo Civil brasileiro.

\section{REFERÊNCIAS}

BRASIL. Constituição da República Federativa do Brasil de 1988. Disponível em: <http://www.planalto.gov.br/ccivil_03/constituicao/constituicaocompilado.htm>. Acesso em: 27 set. 2016.

BRASIL. Lei $n^{o} 13.105$, de 16 de março de 2015. Disponível em: <http://www.planalto.gov.br/ccivil_03/_ato2015-2018/2015/lei/113105.htm>. Acesso em: 28 set. 2016.

BAUERMANN, Desirê. Estabilização da Tutela Antecipada. Revista Eletrônica de Direito Processual. REDP. v. VI. Ano 4. Periódico da Pós-Graduação Stricto Sensu em Direito Processual da UERJ. ISSN 1982-7636, 2010.

BUENO, Cássio Scarpinella. Manual de direito processual civil: inteiramente estruturado à luz do novo CPC, de acordo com a Lei 13.256, de 4-2-2016. 2. ed. São Paulo: Saraiva. 2016.

CÂMARA, Alexandre Freitas. Lições de Direito Processual Civil. v. I. Rio de Janeiro: Editora Freitas Bastos, 1998.

DIDIER JÚNIOR, Fredie. Curso de direito processual civil: teoria da prova, direito probatório, ações probatórias, decisão, precedentes, coisa julgada e antecipação dos efeitos da tutela. 11. ed. v.2. Salvador: Ed. Jus Podivm, 2016.

DINAMARCO, Cândido Rangel. Tutela jurisdicional. São Paulo: Revistas de Processos, ano 21, n. 81, 1996.

GRECO, Leonardo. A tutela de urgência e a tutela de evidencia no Código de Processo Civil de 2014/2015. Rio de Janeiro: Revista Eletrônica de Direito Processual Civil. 2014. ISSN 1982-7636. Disponível em:< http://www.e-

publicacoes.uerj.br/index.php/redp/article/download/14541/15862>. Acesso em 09. abr. 2017.

LEONEL, Ricardo de Barros. Tutela jurisdicional diferenciada. São Paulo: Revista dos Tribunais, 2010.

MARCATO, Antônio Carlos. O processo monitório brasileiro. São Paulo: Malheiros, 1998.

MITIDIERO, Daniel. Da tutela provisória. Breves comentários ao Código de Processo Civil. Teresa Wambier, Fredie Didier Jr. Eduardo Talamini e Bruno Dantas (coord.). São Paulo: RT, 2015. 
NERY JÚNIOR, Nelson. Princípios do processo civil na Constituição Federal. São Paulo: Revista dos Tribunais RT, 2002.

PISANI, Andrea Proto. Sulla tutela giurisdizionale diferenziata. Padova: Rivista di Diritto Processuale, v. XXXIV (II Serie), 1979. p. 539-591.

REDONDO, Bruno Garcia. Estabilização, modificação e negociação da tutela de urgência antecipada antecedente: principiais controvérsias. Revista de Processo. São Paulo: RT, a 40, v. 244. Jun. 2015. p. 167-194.

SOUZA, Artur César de. Tutela provisória: tutela de urgência e tutela de evidência. São Paulo: Almedina, 2016.

THEODORO JÚNIOR, Humberto. Curso de Direito Processual Civil. v. I. $56^{\mathrm{a}}$ ed. Rio de Janeiro: Forense, 2015.

YARSHELL, Flávio Luiz. Tutela jurisdicional. São Paulo: Atlas, 1999. 